\title{
UMA NOVA ESPÉCIE DE SPONGIOPSYLLUS E UM NOVO GÊNERO DE PARMULODINAE (COPEPODA: SIPHONOSTOMATOIDA: ENTOMOLEPIDIDAE) ASSOCIADOS A ESPONJA NO PORTO DA BARRA, BAHIA, BRASIL
}

\author{
Borges, C. C. ${ }^{1,}{ }^{,}$; Neves, E. ${ }^{1}$ \& Johnsson, R. ${ }^{1}$ \\ ${ }^{1}$ Universidade Federal da Bahia (UFBA), Campus Ondina, \\ Laboratório de invertebrados marinhos: Crustacea, cnidaria e fauna associada (LABIMAR). \\ *Autor correspondente: camilacborges.bio@gmail.com
}

\begin{abstract}
Entomolepididae é uma pequena família de copépodes sifonostomatóides encontrada nos principais oceanos no mundo. Atualmente apresenta onze espécies descritas, classificadas em sete gêneros e desses apenas três ocorrem no Atlântico: Parmulodes C. B. Wilson, 1944, Parmulella Stock, 1992 e Spongiopsyllus Johnsson, 2000. Apenas o gênero Spongiopsyllus não é monotípico e apresenta duas espécies descritas, $S$. adventicius Johnsson 2000 e S. redactus Canário et al. 2012, associadas a Aplysina sp. Nardo, 1834 e Mussismilia hispida (Verrill, 1901), respectivamente, ambas registradas para o nordeste do Brasil. Estudos realizados nos costões rochosos do Porto da Barra, na Baía de Todos-os-Santos, revelaram uma nova espécie do gênero, que distingue-se dos seus congêneres por apresentar variação em pelo menos seis apêndices: 1) Artículos antenulares; 2) Endópodo da antena; 3) Ornamentação da maxila; 4) Formato do estilete mandibular; 5) Endópodo do maxilípede e 6) Padrão de cerdas das pernas natatórias. Tal combinação de caracteres nos leva a crer que o exemplar analisado trata-se de uma nova espécie e com o presente trabalho Spongiopsyllus passará a contar com três espécies descritas. Na mesma localidade, um outro entomolepidídeo foi encontrado e ao ser analisado não se encaixou em nenhum dos gêneros já propostos para a família. Embora apresente certas similaridades com Parmulodes verrucosus, esse animal possui um conjunto de caracteres incompatíveis com a diagnose do mesmo, sobretudo no que tange a pelo menos 6 caracteres: (1) Antênula 16-segmentada e com padrão de fusão diferente; (2) Endópodo da antena 3- segmentado com fórmula 0,0,1; (3); Palpo mandibular 1-segmentado; (4) Sifão ornamentado com um tufo de cerdas da ponta; (5) Maxilípede 5-segmentado e (6) Perna quatro totalmente ausente. Entretanto redescrições de $P$. verrucosus não baseadas na espécie tipo revelaram características diferentes do apresentado originalmente, principalmente na antênula, e portanto assemelham-se a nova espécie aqui registrada. Uma revisão detalhada conduzida no material tipo confirmou as características do trabalho original e reforçou as distinções em relação a espécie descoberta no Brasil, sendo portanto necessário criar um novo gênero para alocar a mesma.
\end{abstract}

Palavras-chave: taxonomia, fauna associada, copépodes simbiontes. 